\title{
A Research on the Relationship of Charismatic Leadership Behaviors of Agricultural Cooperative Managers With Cooperative Shareholders' Performance and Satisfaction
}

\author{
Necdet Bilgin \\ Celal Bayar University, Manisa, Turkey \\ Aykut Işleyen \\ Hitit University, Çorum, Turkey
}

\begin{abstract}
In this study, the cooperative shareholders' performance and satisfaction were investigated as antecedent. Charismatic leadership of cooperative managers has been identified as antecedent. In addition, shareholders' age, education, land size, and duration of membership in the cooperative were investigated to have effect on the shareholder's performance and satisfaction. Charismatic leadership of cooperative managers is the subject of research on the effects of performance and satisfaction of the cooperative shareholders. A field survey was conducted. This study has been applied to Çukobirlik, an agricultural sale cooperative in East Mediterranean of Turkey. The researchers collected data by random questionnaire method. The research data were collected from 155 cooperative shareholders. For the data, exploratory factor, correlation, and regression were analyzed. The results of this analysis show that there is a meaningful relationship between charismatic leaders and the performance and satisfaction of shareholders for these cooperatives. Another result, there is significant relation between land size of cooperative shareholders and the performance and satisfaction of cooperative shareholders.
\end{abstract}

Keywords: charismatic leadership, agricultural cooperative, cooperative shareholder's performance and satisfaction

\section{Introduction}

Cooperatives are organizations that have social and economic perspectives. Cooperatives act as any private company in the free market that seeks revenue, because their shareholders the cooperatives member orientated and their social aspects are brought forward (Davis, 1999). In today's standards, for a cooperative to be competitive in the market, it has to bring forward its economic aspects. Globalization and competition affect the cooperatives' competitiveness. It also has difficulties in responding to the competitive market. It can be said that these difficulties cause a negative reaction between the shareholders and the cooperative. The expectations of shareholders rather than being social such as reciprocity, helping one another, and working together have become more focused on the economic aspects such as the increase of sales revenue, increase of profits, and

Necdet Bilgin, associate professor, doctor, Faculty of Economics and Administrative Sciences, Celal Bayar University, Manisa, Turkey.

Aykut Işleyen, assistant professor, doctor, Faculty of Economics and Administrative Sciences, Hitit University, Çorum, Turkey.

Correspondence concerning this paper should be addressed to Necdet Bilgin, Faculty of Economics and Administrative Sciences, Celal Bayar University, Manisa, Turkey. 
being more satisfied with their expectations and outcomes. Indeed, there are scholars that write about the shift of the expectations and purpose of joining of cooperative shareholders from cooperatives to more economic aspects. According to these scholars, the increase of competition has created pressure on both cooperatives and their shareholders to aspire to more economic goals (Karantininis \& Zago, 2001; Österberg \& Nilsson, 2009). There are many factors that give a disadvantage to cooperatives in the competitive market. These come from the structure of the cooperative such as control problem, free-rider problem, horizon problem, and decision-making problem, which makes competitiveness of cooperative more difficult (Cook, 1995). Fulton (2001) stated another important factor that creates challenges for cooperatives in being competitive, that is leadership. The leadership of cooperatives is an essential in competition in the free market and overcoming challenges. The presence of leadership qualities in the management of a cooperative influences, leads and creates action in achieving common goals of shareholders (Fulton \& Giannakas, 2001). Therefore, with the presence of quality leadership, it is expected to influence the performance of shareholders. It is evident in literature that organizations with quality leadership show positive signs in the satisfaction of its workers, performance, and team coherence (Arnold, Barling, \& Kelloway, 2001). When management possesses charismatic leadership behaviors, it affects the performance of the organization. These leaders develop strategic options, establish a vision, and comprehend information, and their experiences also affect the performance of the organization (Waldman, Javidan, \& Varella, 2004). Alliston and Diaz (2005) stated that in the agricultural sector, the current status quo cannot be sustained. The charismatic leader takes actions by establishing a vision for the organization and using the human urge to succeed, and states that it can change the current situation. These leaders in times of uncertainty will help organizations. When the research looks at the social structure of the agricultural sector and of cooperatives of Turkey, the role of the charismatic leader has been seen as ideal for this position and research on the effects of these leaders on the cooperative has been studied. Literatures state how few studies have been done on the topic of leaders and the effects on organizations (Shapira, 2013). In this context, very few studies on the outcomes of leadership in agricultural cooperatives have been studied. In particular, in the literature, there are few studies on charismatic leadership and cooperative managers. This study differs from previous studies applied empirically cooperative managers to charismatic leadership. In this respect, the main purpose of the study, with charismatic leadership behavior of cooperative managers, is to investigate the existence of a relationship between the shareholders' performance and satisfaction. Also, the relationship between the performance and satisfaction of shareholders and cooperative shareholders'age, education, size of land, and duration in cooperative was examined. The research has two sections, namely, theoretical and practical. In the theoretical section, the framework of relevant literature, research variables of charismatic leadership, performance and satisfaction of shareholders, and demographic characteristics were considered. In the practical section, making of the scales used in previous research, a questionnaire was created. Questionnaire was applied to 155 cooperative shareholders in Çukobirlik. Questionnaire response, exploratory factor, correlation, and regression analysis were performed.

\section{Literature Review}

\section{Charismatic Leadership Behavior of Cooperative Managers}

Leadership is an important topic (Shapira, 2013). Since agricultural cooperatives are organizations that aim for success of their shareholders, leadership becomes an important factor. The cooperative management is also in the position of leadership in agricultural cooperatives. Cooperative management team is elected by 
shareholders to manage the cooperative for a certain period. The management is responsible for the successful management of the cooperative and its activities. The management of the cooperative, with its expertise, knowledge, experiences, and envisions of future situations is responsible for leading the cooperative activities and setting its political and daily functions (Prakash, 2005). The cooperative leaders thrive to have a better performance of the cooperative by following the vision, mission, and values set forth by the cooperative (Cropp, 2005). They play a critical role in the success of the cooperative. The cooperative management is responsible for establishing cooperation between shareholders, and meeting the demands of these shareholders (Dunn, Crooks, Frederick, Kennedy, \& Wadsworth, 2002). As a leader, the cooperative management develops strategies and policies in order to achieve the aims of the cooperative. Managers, by leadership in the cooperative, the cooperative's services are developed institutionally. Fulfilling the aims of the cooperatives and having success of the shareholders are the aim of the leaders of the cooperative (Davis, 1999). An elected leader in a cooperative (for example the cooperative president) is influential in establishing the business strategies of the cooperative. A successful business strategy protects cooperative from inefficiency and competitive market traps. An effective strategy results positively to the cooperative, and also the shareholders are affected by these positive results (Fulton, 2001).

According to the charismatic leader theory, charismatic leaders are influential to their followers. This leader embraces and encourages the spirit of cooperation of its followers (Conger, Kanungo, \& Menon, 2000). Charismatic leader guides and motivates its followers to achieve their goals (Lee \& Chang, 2006). The management that possesses the characteristics of a charismatic leader has a better organizational vision and organizational values is strengthened. So, as followers reach their goals collectively (De Hoogh, Den Hartog, Kopman, Thierr, Den Berg, Der Weidea, \& Wilderoma, 2005; Choi, 2006). Charismatic leaders have the qualifications and the know-how needed to lead the cooperation to success. Leaders, who lead a company to entrepreneurial success, are able to be decisive in face of competition, win a military success over a power army, and gain successful social reforms against an oppressive and colonial administration are some of the qualifications of a charismatic leader working towards achieving their goals (House \& Aditya, 1997). A charismatic leader always takes advantages of the opportunities of the market and of the cooperation; these types of leaders are entrepreneurs and reformists. Charismatic leaders bring into action change and innovation (Conger, 1999). Cooperative leaders follow the developments within the market place in order to help in the cooperatives growth and development and competitiveness in economic, technological, and market opportunities. By evaluating the current situation, the leader works to find new paths to take in order to gain the goals of the cooperative. At the same time, this is the exact and required management strategy to be taken in order for a cooperative to be competitive. The identification of the needs of the cooperative partners is also one of the tasks of the cooperative leader. The purpose of the cooperative is to achieve the goals of its shareholders. For this reason, meeting the common needs and demands of the shareholders is one of the most important tasks of the leaders. Determining the vision of the cooperative and guiding the shareholders, by this vision, being knowledgeable about the market in achieving the goals of the cooperative is important, these are the qualifications of the cooperative leader in order to lead the cooperative to success in a globalized competitive market.

\section{Cooperative Shareholders' Performance and Satisfaction}

If the shareholders are not pleased with the functions of the cooperative, the shareholder will have negative 
view of them. Negative views of shareholders of the cooperative will create negative reactions. According to literature, cooperative leaders (management) who do not meet the needs and satisfaction of their shareholders cannot be insightful. Cooperatives cannot exist very long with unsatisfied shareholders who do not participate in cooperative events. The reasons for the failures of cooperatives are the lack of participation of shareholders and the unsuccessful management by the leaders of the cooperative (Bhuyan, 2007). The satisfaction of shareholders reflects their relation with the cooperative and therefore it is an important determent in the success of the cooperative. The leadership qualities of management and of a vision for the cooperative are indicators in the satisfaction of shareholders and also the success of cooperative (Cook, 1993). A leader, at times, is one that makes decisions on what to do, directs individuals and organizations, and foresees situations to act upon (Paşa, 2000). Again, the style and character of the leader play a key role in affecting the performances of its followers (Berson, Shamair, Avolio, \& Popper, 2001). During the execution of a job, the presence of leadership behavior can improve the performance of groups and organizations (Paşa, Kabasakal, \& Bodur, 2001). In a cooperative's success, the leaders are identified to be an important determinant (Kyriakopoulos, Meulenberg, \& Nilsson, 2004). Also, there is a relation between the leaders of cooperatives who bring financial success to cooperatives as well as commitment to cooperative shareholders to the cooperative (Fulton \& Giannakas, 2007). Cooperative shareholders' performance and satisfaction will be increased when they trust their cooperative managers (leaders) (Morrow Jr, Hansen, \& Pearson, 2004). Charismatic leaders also motivate and satisfy its followers by increasing the performances of them (Conger et al., 2000). Research shows that charismatic leaders increase the performances to the highest levels of each person, business unit, and organizations (Shea \& Howell, 1999). In this regard, it can be identified that there is a relation between the charismatic leader and the performance of the group (De Groot, Kiker, \& Cross, 2000). There is research on the positive effects of charismatic leaders on business performances. These positive indicators, such as business profitability and controlling costs are financial criteria (Koenel, Vogelaar, \& Soeters, 2002). According to Shamir, House, and Arthur (1993), empirical study was found that the effective performance and satisfaction of the followers was affected by the charismatic leader. In this context, charismatic leadership behaviors of cooperative managers are likely to positively affect the performance of its shareholder. Because cooperatives act so as to positively affect the performance and satisfaction of shareholders are among the goals of cooperatives. In this sense, cooperative managers play an important role. Therefore, the presence of charismatic leadership behaviors of cooperative managers is likely to affect the performance and satisfaction of shareholders positively.

Performance and satisfaction of the shareholders in the agricultural cooperatives meanings are: the financial indicators such as the increase in profits and revenue of the shareholders through the cooperative, also non-financial criteria, such as meeting the satisfaction and expectations of the shareholders through the cooperative have occurred (Hansen, Morrow Jr, \& Batista, 2002). In literature, there are findings show leadership and charismatic leadership in the direction that affect the performance of individuals, groups, and organizations. In the presence of charismatic leadership of cooperative managers, a positive effect on the performance of the cooperative and in this context the performance of the shareholders can be seen.

\section{Demographic of Shareholders (Members' Characteristics)}

Understanding the demographics of the cooperative relationship with the shareholders is important for the development of performance and satisfaction and continuity of cooperative management of the cooperative (Bhuyan, 2007). In this context, the land size of cooperative shareholders, educational level, age, and the 
relation between the performances and satisfaction of shareholders in cooperative partnerships with time that they have been partners with the cooperative have been investigated. The attitudes towards cooperatives of farmers according to their farm size have been investigated in literature. Medium sized farmers' attitudes towards the cooperative have been found to be positive, however larger sized farmers are more critical. In other studies, no such correlation has been found (Österberg \& Nilsson, 2009). In agricultural cooperatives, the land size of the shareholder, the duration in cooperative shareholder, the time in farming, and the educational levels revealed the existence of a relationship between performance and satisfaction of the shareholders that has been investigated (Hansen et al., 2002; Bakucs, Ferto, \& Szabo, 2007). A relation has been found to be present between the shareholders duration in the cooperative and the performance and satisfaction investigated (Hansen et al., 2002). Also in cooperatives, horizon problems' dissatisfaction is expressed especially by the elder shareholders (Österberg \& Nilsson, 2009).

\section{Research Methodology}

\section{Research Model and Hypotheses}

The variables of the theoretical framework, model, and hypothesis investigations were constructed in the follows Figure 1 and hypotheses. Research models as predictors of cooperative shareholders performance and satisfaction were charismatic leadership of cooperative managers. Also cooperative shareholders' age, duration of cooperatives, education, and land size are taken as the determinants of shareholders' performance and satisfaction. Research model is given in Figure 1.

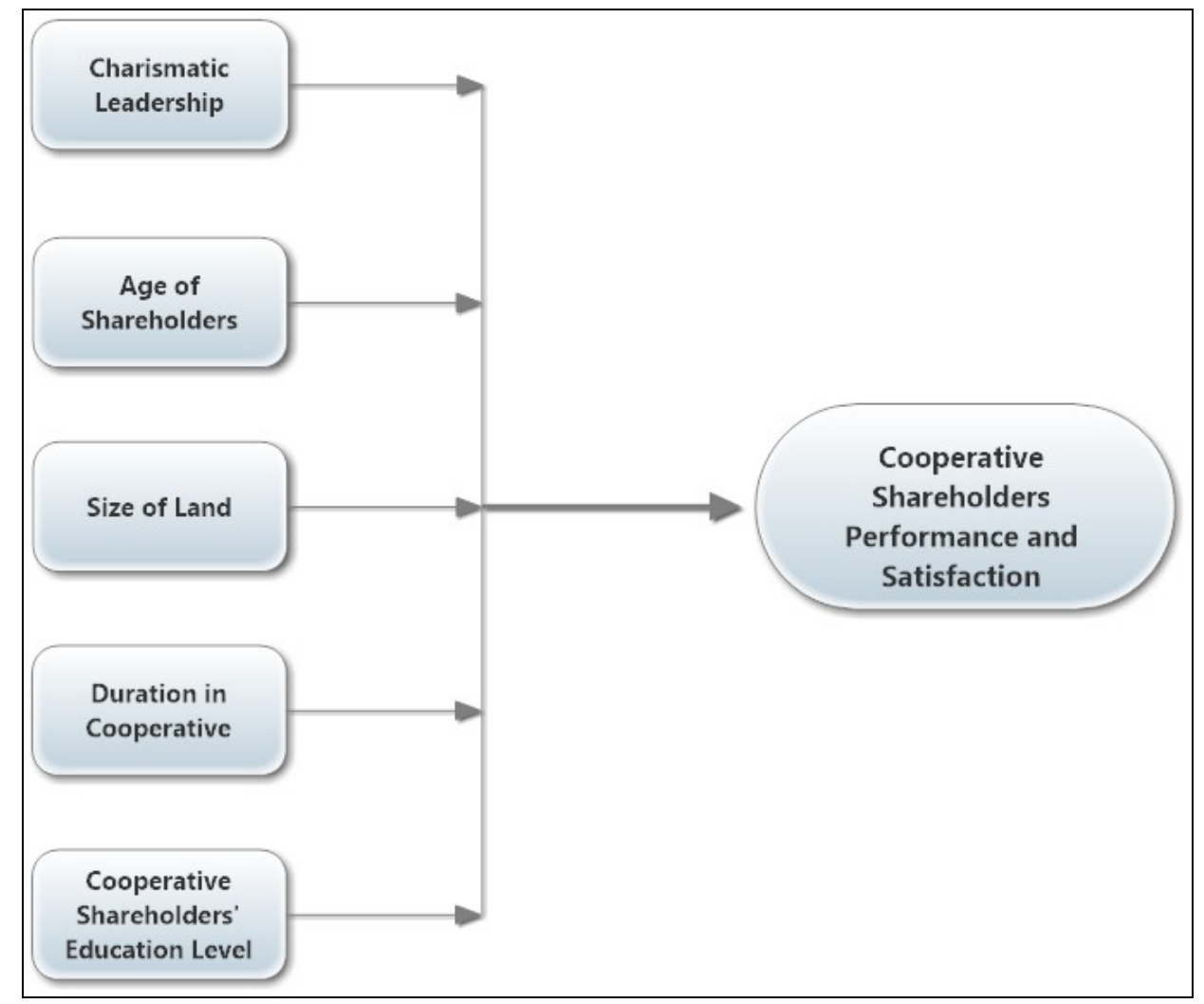

Figure 1. Research model. 
Research hypotheses were created below, according to literature. The dependent variable is the performance and satisfaction of cooperative shareholders. The independent variables are charismatic leadership and demographic variables (age, education, duration of the cooperative, and the land size).

Research hypotheses in this framework have been established in the following way:

Hypothesis 1 . There is a relationship between the charismatic leadership of cooperative management and the shareholders' performances and satisfaction.

Hypothesis 2. There is a relationship between cooperative shareholders' demographic characteristics: a) land size, b) shareholder's age, c) education, and d) duration of the cooperative and the shareholders' performance and satisfaction.

\section{Research Universe, Sample and Used Scales}

Research for the hypotheses has been done with the data collected and tested at the Çukobirlik cooperative. Çukobirlik does the marketing of cotton, soybean, sunflower and peanut products, and provides input (such as seeds, fertilizer, etc.) to the shareholders. Çukobirlik located in Turkey's Southeastern Anatolian and the Eastern Mediterranean regions, 14-unit co-op continues to operate in 14 provinces with 65,000 shareholders. In this study, the data have been collected by a questionnaire from the provinces of Hatay, Adana, Mersin, and Osmaniye Çukobirlik of shareholders. In these provinces, the number of shareholders is 18,426 and only 155 shareholders participated in the research questionnaire. Researchers randomly found Çukobirlik shareholders in various villages, towns, and districts to fill the survey face to face. To measure the charismatic leadership of cooperative managers in the study, 20 propositions of the Revised C-K Leadership Scale of Charismatic scale were used (Conger, Kanungo, Menon, \& Mathur, 1997). Conger et al. (1997) developed this scale in order to measure collective values of societies. Since Turkey is a collective values society (Hofstede, 1980), this scale was used. In order to measure the performance and satisfaction of cooperative shareholders, the scale developed by Morrow Jr et al. (2004) was used. Propositions were expressed as a 7-point Likert scale $(1=$ strongly disagree, $7=$ strongly agree).

\section{Research Results}

\section{Demographic Characteristics}

Demographic data of the shareholders participating in the study are given in Table 1. Participants' age ranged from 30 to 85 , and the average is 57 . Land sizes of shareholders are between 10 and 2,000 decares of land with an average size of 230 decares.

\section{Factor Analysis}

With charismatic leadership and performance and satisfaction of satisfaction data derived from the survey, an exploratory factor analysis was conducted. Kaiser-Meyer-Olkin (KMO) test was performed for compliance with the factor analysis of the data set. KMO test result of 0.942 shows that the data set is appropriate for analysis (Eroğlu, 2008, p. 322). Explained variance was 88.352\%. Bartlett's test of sphericity was 8,525.927. Factor loadings seem to be over 0.700 . Factor distribution factor table is shown in Table 2.

\section{Correlation and Regression Analysis}

Analysis of correlation among variables, the mean, and coefficients of variable reliability is shown in Table 3. Scale of reliability are given in parentheses that the values are above 0.70 which means the results are reliable (Nunnally, 1978). 
Table 1

Demographic Data of the Shareholders

\begin{tabular}{|c|c|c|c|}
\hline Information & Groups & $\mathrm{N}$ & Percentage \\
\hline \multirow{7}{*}{ Age } & $18-24$ & - & 0 \\
\hline & $25-34$ & 2 & 1.2 \\
\hline & $35-44$ & 26 & 16.5 \\
\hline & $45-54$ & 40 & 25.8 \\
\hline & 55 years old and above & 85 & 55.2 \\
\hline & Unspecified & 2 & 1.3 \\
\hline & Total & 155 & 100 \\
\hline \multirow{8}{*}{ Education } & Illiterate & 2 & 1,3 \\
\hline & Literate & 15 & 9.7 \\
\hline & Elementary school & 87 & 56.1 \\
\hline & Junior high & 17 & 11.0 \\
\hline & High school & 27 & 17.4 \\
\hline & Vocational school & 3 & 1.9 \\
\hline & University & 4 & 2.6 \\
\hline & Total & 155 & 100 \\
\hline \multirow{5}{*}{ Computer usage } & Often & 5 & 3.2 \\
\hline & Sometimes & 15 & 9.7 \\
\hline & Never & 133 & 85.8 \\
\hline & Unspecified & 2 & 1.3 \\
\hline & Total & 155 & 100 \\
\hline \multirow{9}{*}{ Land sizes (decares) } & $0-25$ & 13 & 8.3 \\
\hline & $26-50$ & 23 & 14.6 \\
\hline & $51-75$ & 15 & 9.6 \\
\hline & $76-100$ & 23 & 14.6 \\
\hline & $101-250$ & 39 & 24.9 \\
\hline & $251-1,000$ & 37 & 23.9 \\
\hline & More than 1,000 decares & 9 & 2.4 \\
\hline & Unspecified & 1 & 0.6 \\
\hline & Total & 155 & 100 \\
\hline \multirow{7}{*}{ Duration in cooperative } & $0-10$ years & 25 & 16.4 \\
\hline & $10-20$ years & 44 & 29.0 \\
\hline & 20-30 years & 41 & 27.0 \\
\hline & $30-40$ years & 33 & 21.7 \\
\hline & More than 40 years & 9 & 5.9 \\
\hline & Unspecified & 3 & 1.9 \\
\hline & Total & 155 & 100 \\
\hline
\end{tabular}

Table 2

Factor Analysis

Explain the variance (E.V.)\%88.352;

KMO, 942; Bartlett's test of sphericity 8,525.927

Cooperative managers, engage in unconventional behavior in order to achieve organizational goals.

$1 * \quad 2 *$

Cooperative managers, take high personal risks for the sake of the organization.

0.891

Cooperative managers, recognize the abilities and skills of other members of the organization.

0.883

Cooperative managers, recognize the limitations of other members of the organization.

$0.883 \quad 0.413$

$0.876 \quad 0.420$ 
Table 2 continued

\begin{tabular}{|c|c|c|}
\hline $\begin{array}{l}\text { Explain the variance (E.V.)\%88.352; } \\
\text { KMO, 942; Bartlett's test of sphericity } 8,525.927\end{array}$ & $1 *$ & 2* \\
\hline Cooperative managers, use nontraditional means to achieve organizational goals. & 0.873 & \\
\hline Cooperative managers, often incur high personal cost for the good of the organization. & 0.871 & \\
\hline Cooperative managers, often exhibit very unique behavior that surprises other members of the organization. & 0.870 & \\
\hline Cooperative managers, entrepreneurial; seize new opportunities in order to achieve goals. & 0.868 & \\
\hline $\begin{array}{l}\text { Cooperative managers, readily recognize new environmental opportunities (favorable physical and social } \\
\text { conditions) that may facilitate achievement of organizational objectives. }\end{array}$ & 0.867 & \\
\hline Cooperative managers, have vision; often bring up ideas about possibilities for the future. & 0.865 & 0.409 \\
\hline $\begin{array}{l}\text { Cooperative managers, in pursuing organizational objectives, engage in activities involving considerable } \\
\text { personal risk. }\end{array}$ & 0.863 & 0.434 \\
\hline $\begin{array}{l}\text { Cooperative managers, readily recognize constraints in the physical environment (credit, seed and marketing } \\
\text { of products) that may stand in the way of achieving organizational objectives. }\end{array}$ & 0.853 & 0.418 \\
\hline $\begin{array}{l}\text { Cooperative managers, readily recognize constraints in the organization's social and cultural environment } \\
\text { (loss of shareholder support, different ideas) that may stand in the way of achieving organizational objectives. }\end{array}$ & 0.853 & \\
\hline $\begin{array}{l}\text { Cooperative managers, often expresse personal concern for the needs and feelings of other members in the } \\
\text { organization. }\end{array}$ & 0.850 & 0.406 \\
\hline Cooperative managers, show sensitivity for the needs and feelings of other members in the organization. & 0.849 & 0.415 \\
\hline Cooperative managers, exciting public speaker. & 0.840 & \\
\hline Cooperative managers, influence others by developing mutual liking and respect. & 0.837 & 0.424 \\
\hline Cooperative managers, consistently generate news ideas for the future of the organization. & 0.834 & 0.429 \\
\hline $\begin{array}{l}\text { Cooperative managers, inspirational; able to motivate by articulating effectively importance of what } \\
\text { organizational members are doing. }\end{array}$ & 0.816 & 0.423 \\
\hline Cooperative managers, provide inspiring strategic and organizational goals. & 0.775 & \\
\hline My shareholdership, have resulted in increased profits. & & 0.886 \\
\hline My shareholdership, have resulted in increased sales revenue. & & 0.881 \\
\hline Overall, I am satisfied with the results of my shareholdership. & & 0.854 \\
\hline Overall, I am getting what I bargained for when I joined this organization. & & 0.803 \\
\hline
\end{tabular}

Notes. $1 *$ charismatic leadership behavior of cooperative mangers; $2 *$ performance and satisfaction of cooperative shareholder.

Table 3

Means, Standard Deviations, and Correlations

\begin{tabular}{|c|c|c|c|c|c|c|c|c|}
\hline & M & S.D. & 1 & 2 & 3 & 4 & 5 & 6 \\
\hline 1. Charismatic leadership & 4.0162 & 1.8958 & 1 & $(0.993)$ & & & & \\
\hline $\begin{array}{l}\text { 2. Shareholder } \\
\text { performance-satisfaction }\end{array}$ & 4.0194 & 1.8661 & $0.746^{* *}$ & 1 & $(0.952)$ & & & \\
\hline 3. Land size & 230.44 & 300.570 & -0.052 & 0.155 & 1 & & & \\
\hline 4. Duration in cooperative & 24.08 & 11.327 & $-0.193 *$ & $-0.238^{*}$ & $-0.296 * *$ & 1 & & \\
\hline 5. Education & - & - & 0.090 & 0.141 & $0.233 * *$ & $-0.200 *$ & 1 & \\
\hline 6. Age & 57.04 & 12.330 & -0.098 & $-0.181 *$ & $-0.297 * *$ & $0.650 * *$ & $-0.449 * *$ & 1 \\
\hline
\end{tabular}

Notes. ${ }^{* *} p<0.01$ (2-tailed); ${ }^{*} p<0.05$ (2-tailed). M: means; S.D.: standard deviations.

Gradual regression analyses between variables were done. Dependent variable is the performance and satisfaction of cooperative shareholders. The first stage of regression analysis showed a significant relationship between managers with charismatic leadership behaviors and the performance and satisfaction of shareholders. In the second stage of regression analysis of shareholder's age, education levels, and the size of land, no relationship between performance and satisfaction of shareholders was found, however a relation between shareholder's performance-satisfaction in a cooperative duration was present. The third stage of regression 
analysis charismatic leadership as an independent variable with land size, duration in cooperative, education, and the age of the shareholders, their relation on the shareholder performance and satisfaction was investigated. A positive correlation between charismatic leadership and the performance and satisfaction of shareholders and also with land size has been shown to have a relationship. Hypothesis 1 has been supported. There is a negative relation between duration in cooperatives and the performance and satisfaction of cooperative shareholders. In addition, there is a significant relationship between the size of land and the performance-satisfaction of cooperative shareholders. Hypotheses $2 \mathrm{a}$ and $2 \mathrm{~d}$ have been supported. However, cooperative shareholders' age and education have no correlation between the performance and satisfaction of shareholders. Hypotheses $2 b$ and $2 \mathrm{c}$ haven't been supported.

Table 4

Regression Analysis (Dependent Variable: Performance-Satisfaction of Shareholders)

\begin{tabular}{lllllll}
\hline \multirow{2}{*}{ Independent variable } & \multicolumn{3}{c}{ Stage 1 } & \multicolumn{2}{c}{ Stage 2 } & \multicolumn{2}{c}{ Stage 3 } \\
\cline { 2 - 7 } & $\beta$ & $t(p)$ & $\beta$ & $t(p)$ & 0.750 & $13.737(0.000)^{* *}$ \\
Charismatic leadership & 0.746 & $13.869(0.000)^{* *}$ & - & - & 0.174 & $3.046(0.003)^{* *}$ \\
Land size & - & - & 0.078 & $0.906(0.366)$ & -0.019 & $-0.260(0.795)$ \\
Duration in cooperative & - & - & -0.225 & $-2.073(0.040)^{*}$ & -0.019 & $0.135(0.893)$ \\
Education & - & - & 0.079 & $0.863(0.390)$ & 0.008 & $-0.411(0.681)$ \\
Age & - & - & 0.042 & $0.363(0.717)$ & -0.032 & $42.544^{* *}$ \\
$F$ & $192.357^{* *}$ & $2.607^{*}$ & & 0.598 & \\
$R^{2}$ & 0.557 & 0.068 & & 0.584 & \\
Adjusted $R^{2}$ & 0.554 & 0.042 & & & \\
\hline
\end{tabular}

\section{Conclusion}

The relations between the shareholders' duration in cooperative, land size, education, age, cooperative manager's charismatic leadership behaviors, and shareholders' performance and satisfaction were investigated. In this sense, leadership in cooperatives is an important topic. This research is an experimental research on charismatic leadership behaviors of cooperative managers. The administrators of the cooperative management must successful manage cooperatives to respond to competition in the free market conditions, and at the same time, deliver the objectives of its cooperative partners. In doing so, acting as cooperative managers of an entrepreneur, realizing cooperative internal and external opportunities and threats, is a must way of management of a cooperative. Indeed, it can be said that the main reason for the failure of cooperatives in Turkey is the inability to adapt to the free market mechanism. Therefore, the leadership of the cooperative manager is an important element in ensuring the collective act together as shareholders. Cooperative managers with charismatic leadership, in today's intense competitive environment seek ways to take the cooperative to success. With entrepreneurial characteristics, strategies that will lead to success in the competition in the free market are applied. Effective strategies will provide the edge over the competition as a positive influence on the cooperative. The manager, by taking risks works to deliver the objectives of the cooperative and its shareholders, and directs the cooperative and shareholders in accordance with certain purposes.

Cooperative manager's charismatic leadership behaviors seem to affect the performance and satisfaction of shareholders in a positive way. In literature, the behavior of the leadership is said to improve group and business's performance (Paşa et al., 2001). Again, it was found that the performance of the charismatic leader 
of the group turned out more than the other business unit leaders (Shea \& Howell, 1999). In this study, the existence of a positive relationship between the leadership qualities in common with the performance of cooperative managers is said to be similar to the literature. Shareholders, to gain sales revenue through cooperatives, to achieve profitability, to meet the expectations of the cooperative, and to achieve its objectives through the cooperative, will have a positive impact on its performance and satisfaction. Due to the large number of farmers in Turkey, the sizes of business are small and scattered in structure, and for such reasons the impact of the agricultural sector in the organization are inadequate and are unable to compete in the free market. For these reasons, the cooperative is a position marker in the performance of shareholders. Cooperative managers play an important role in the success of the cooperative. Therefore, it can be said that the charismatic manager's behavior affects the performance of cooperatives and shareholders. In this study, the support of Hypothesis 1 is shown. It can be said that the charismatic leadership style guides and meets the expectations of the farmers in Turkey. In fact, this study shows the main determinants of charismatic leadership behavior of managers in the performance of the Çukobirlik shareholders.

In previous studies, it was found the impact on outcome of charismatic leadership's followers (Fuller, Patterso, Hester, \& Stringer, 1996; Huang, Cheng, \& Chou, 2005). In this study, unlike previous studies were conducted in agricultural cooperatives, parallel results were obtained with previous studies. Cooperative managers' charismatic leadership behaviors affect the outcomes of cooperative shareholders. Charismatic leadership behaviors of the cooperative managers can provide more professional movement in the free market. In this case, by contributing to the cooperative's success, improving the performance of cooperative shareholders, cooperative managers can improve the activities of cooperatives with charismatic leadership behavior. Especially, economic terms such as reducing costs, can be effective in evaluating the product of cooperative shareholders. In this context, it is important that sensitive cooperative internal and external environment should not be forgotten. These leaders should take care of the change and innovation and take the responsibility for the cooperative's success.

It has been found that as land size increases, it positively affects the shareholder's performance. Duration in cooperative has a negative and reducing effect on shareholder's performance. It can be said that the cooperative does not meet the expectations of its shareholders who spend long duration in the cooperative. In addition, the old farmer is reported to be less positive for cooperatives in the literature (Österberg \& Nilsson, 2009). In this study, a finding similar to those results is obtained in the literature. The cooperative has a positive impact on the performance of the large shareholder, because co-operatives are an alternative to sell their products.

\section{Limitations and Further Research}

This study is intended to make a contribution to the literature in the area of charismatic leadership of cooperative managers. Research limitation, since the research study is done at Çukobirlik, only an agricultural sales cooperative and a region have been researched. That is, data are collected from only one source.

Similar research can be done in various different agricultural sales cooperatives and different types of cooperatives (consumer, housing, etc.). Also the investigation of different leadership behaviors of cooperative managers will be especially useful for cooperatives in Turkey. Another research topic is investigating the relationship between charismatic leadership and cooperative performance. 


\section{References}

Alliston, J. G., \& Diaz, F. (2005). Leadership in a changing agriculture in UK. International Farm Management Associatıon (IFMA), 15th Congress-Brazil.

Arnold, K. A., Barling, J., \& Kelloway, E. K. (2001). Transformational leadership or the iron cage: Which predicts trust, commitment and team efficacy? Leadership \& Organization Development Journal, 22(7), 315-320.

Bakucs, L. Z., Ferto, I., \& Szabo, G. G. (2007). The impact of trust cooperative membership performance and satisfaction in the Hungarian Horticulture. Paper prepared for presentation at the joint IAAE-104th EAAE Seminar Agricultural Economic and Transition, Corvinus University of Budapest (CUB), Budapest, Hungary, September.

Berson, Y., Shamair, B., Avolio, B. J., \& Popper, M. (2001). The relationship between vision strength, leadership style and context. The Leadership Quarterly, 12, 53-73.

Bhuyan, S. (2007). The "people" factor in cooperatives: An analysis of members' attitudes and behavior. Canadian Journal of Agricultural Economics, 55, 275-298.

Choi, J. (2006). A motivational theory of charismatic leadership: Envisioning, empathy, and empowerment. Journal of Leadership and Organizational Studies, 13(1), 24-43.

Conger, J. A., Kanungo, R. N., Menon, S. T., \& Mathur, P. (1997). Measuring charisma: Dimensionality and validity of the Conger-Kanungo scale of charismatic leadership. Canadian Journal of Administrative Sciences, 14, 290-302.

Conger, J. A. (1999). Charismatic and transformational leadership in organizations: An insider's perspective on these developing streams of research. Leadership Quarterly, 10(2), 145-179.

Conger, J. A., Kanungo, R. N., \& Menon, S. (2000). Charismatic leadership and follower effects. Journal of Organizational Behavior, 21, 747-767.

Cook, M. L. (1993). The role of management behavior in agricultural cooperatives. Journal of Agricultural Cooperation, 9, $42-58$.

Cook, M. L. (1995). The future of U.S. agricultural cooperatives: A neo-institutional approach. American Journal of Agricultural Economics, 77(5), 1153-1159.

Cropp, R. (2005). Cooperative leadership, university of Wiscons in center for cooperative. Madison Bulletin 9. Retrieved from http://www.uwcc.wisc.edu/pdf/Bulletins/bulletin_07_05.pdf

Davis, P. (1999). Managing the cooperative difference a survey of the application of modern management the practices in the cooperative context. International Labour Office Ceneva- Switzerland.

De Hoogh, A. H. B., Den Hartog, D. N., Kopman, P. L., Thierr, Y. H., Den Berg, P. T. V., Der Weidea, J. G. V., \& Wilderoma, C. P. M. (2005). Leader motives, charismatic leadership, and subordinates' work attitude in the profit and voluntary sector. The Leadership Quarterly, 16(1), 17-38.

De Groot, T., Kiker, D. S., \& Cross, T. C. (2000). A meta-analysis to review organizational outcomes related to charismatic leadership. Canadian Journal of Administrative Sciences, 17(4), 356-372.

Dunn, J. R., Crooks, A. C., Frederick, D. A., Kennedy, T. L., \& Wadsworth, J. J. (2002). Agricultural cooperatives in the 21 st century. United States Department of Agriculture, Rural Business-Cooperative Service, Cooperative Information Report 60. Retrieved from http://www.rd.usda.gov/files/publications/CIR-60.pdf

Eroğlu, A. (2008). SPSS uygulamalı çok değişkenli istatistik teknikleri (Statistical package for the sciences applied multivariate statistical techniques). In K. Şeref (Ed.), Faktör analizi (factor analysis), Asil Yayın Dağıtım, 3. Basım, Ankara.

Fuller, J. B., Patterso, C. E. P., Hester, K., \& Stringer, D. Y. (1996). A quantitative review of research on charismatic leadership. Psychological Reports, 78(1), 271-287.

Fulton, M. (2001). Leadership in democratic and participatory organizations. Presidential adress to the Canadian agricultural economics society CAES-AAEA annual meeting, Chicago, August 5-8, 1-26. Retrieved from https://www.researchgate.net/profile/Murray_Fulton/publication/240268537_Leadership_in_Democratic_and_Participatory_ Organizations/links/551dca4b0cf29dcabb03372b.pdf

Fulton, M., \& Konstantinos, G. (2001). Organizational commitment in a mixed oligopoly: Agricultural co-operatives and investor owned firms. American Journal of Agricultural Economics, 83, 1258-1265.

Fulton, M., \& Konstantinos, G. (2007). Vertical markets and cooperative hierarchies, the role of cooperatives in the agri-food industry. In K. Karantininis and J. Nilsson (Eds.), Agency and leadership in cooperatives-endogenizing organizational commitment (pp. 93-113). The Netherlands: Springer.

Hansen, M. H., Morrow Jr, J. L., \& Batista, J. C. (2002). The impact of trust on cooperative member retention, performance and satisfaction: An exploratory study. International Food and Agribusiness Management Review, 5, 41-59. 
Hofstede, G. (1980). Culture's consequences: International differences in work-related values. California, CA: Sage Publications, Beverly Hills.

House, R. J., \& Aditya, T. (1997). The social scientific study of leadership: Quo vadis? Journal of Management, 23(3), 409-473.

Huang, M. P., Cheng, B. S., \& Chou, L. F. (2005). Fitting in organizational values the mediating role of person-organization fit between CEO charismatic leadership and employee outcomes. International Journal of Manpower, 26(1), 35-49.

Karantininis, K., \& Zago, A. (2001). Endogenous membership in mixed duopsonies. American Journal of Agricultural Economics, 83(5), 1266-1272.

Kyriakopoulos, K., Meulenberg, M., \& Nilsson, J. (2004). The impact of cooperative structure and firm culture on market orientation and performance. Agribusiness, 20(4), 379-396.

Koenel, B. A. S., Vogelaar, A. L. W., \& Soeters, J. L. (2002). Leadership effects on organizational climate and financial performance: Local leadership effect in chain organizations. The Leadership Quarterly, 13(3), 193-215.

Lee, Y. D., \& Chang, Y. F. (2006). A study on the characters of leaders and followers of charismatic leadership-The example of employees at a port authority. The Business Review, Cambridge, 5(1), 263-269.

Morrow Jr, J. L., Hansen, M. H., \& Pearson, A. W. (2004). The cognitive and affective antecedents of general turst within cooperative organizations. Journal of Managerial Issues, 16(1), 48-64.

Nunnally, J. C. (1978). Psychometric theory (2nd ed.). New York: McGraw-Hill.

Österberg, P., \& Nilsson, J. (2009). Members' perceptions of their participation in the governance of cooperatives: The keys to trust and commitment in agricultural cooperatives. Agribusiness, 25(2), 181-197.

Paşa, S. F. (2000). Türkiye'de yönetim, liderlik ve insan kaynakları uygulamaları (In Turkey, management, leadership and human resources applications). In Z. Aycan (Ed.), Türk Psikologları Derneği Yayınları (Turkish psychologists association publications), Ankara.

Paşa, S. F., Kabasakal, H., \& Bodur, M. (2001). Society, organizations, and leadership in Turkey. Applied Psychology: An International Review, 50(4), 559-589.

Prakash, D. (2005). Enlightened cooperatives inculcate social cohesion and harmony. Rural Development and Management Centre (RDMC), "The Saryu”, J-102 Kalkaji, New Delhi, India.

Shamir, B., House, R., \& Arthur, M. B. (1993). The motivational effects of charismatic leadership: A self-concept based theory. Organizational Science, 4(4), 577-594.

Shapira, R. (2013). Leaders' vulnerable involvement: Essential for turst, learning, effectiveness and innovation in inter-co-operatives. Journal of Co-operative Organization and Management, 1, 15-26.

Shea, C. M., \& Howell, J. M. (1999). Charismatic leadership and task feedback: A laboratory study of their effects on self-efficacy and task performance. Leadership Quarterly, 10(3), 375-396.

Waldman, D. A., Javidan, M., \& Varella, P. (2004). Charismatic leaderhip at the stategic level: A new application of upper echelons theory. The Leadership Quarterly, 15(3), 355-380. 